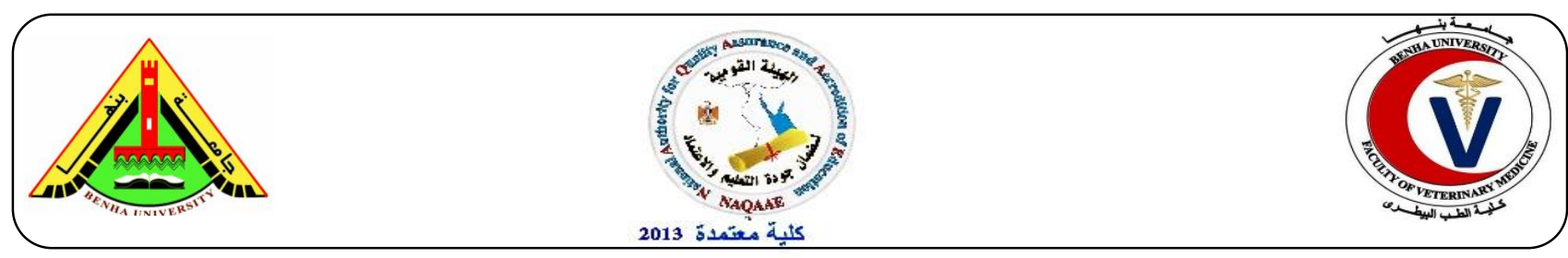

\title{
Biochemical effect of curcumin on experimentally induced myocardial injury in rats
}

\author{
Samy A. Hussein, Mohamed E. Azab, and Sheryhan M. Abdelwahed
}

Department of Biochemistry, Faculty of Veterinary Medicine, Benha University

\section{A B S T R A C T}

Myocardial infarction (MI) is one of the main causes of death from cardiovascular disease. Curcumin was shown to exert potent antioxidant, anti-inflammatory, antiangiogenic, antimutagenic, anticoagulant and antidiabetic activities. This study was done to investigate the protective effects of curcumin in isoproterenol (ISO) induced myocardial injury in rats. Forty-eight rats were divided into 6 equal groups. Group I: (normal control) rats received no drugs. Group II :(curcumin) rats received curcumin (200 $\mathrm{mg} / \mathrm{kg}$ b.wt/day) orally for 30 days. Group III: (acute myocardial infarction) rats injected ISO $\left(20 \mathrm{mg} / \mathrm{kg}\right.$ b.wt /intraperitoneally) twice at the $29^{\text {th }}$ and $30^{\text {th }}$ days of experiment. Group IV: (chronic myocardial infarction) rats injected ISO $(20 \mathrm{mg} / \mathrm{kg}$ b.wt /intraperitoneally) twice at the $1^{\text {st }}$ and $2^{\text {nd }}$ days of experiment. Group V: (acute myocardial infarction + curcumin) rats received curcumin $(200 \mathrm{mg} / \mathrm{kg} \mathrm{b} . \mathrm{wt} /$ day $)$ for 30 days, then ISO was injected twice, at an interval of 24 hours, on the $29^{\text {th }}$ and $30^{\text {th }}$ days .Group VI: (chronic myocardial infarction + curcumin) rats injected ISO at the $1^{\text {st }}$ and $2^{\text {nd }}$ days of experiment and treated with curcumin for 30 days. Blood samples and heart tissue specimens were collected at the end of experimental period (30 days) for determination of serum Creatine kinase MB (CK-MB), Lactate dehydrogenase (LDH), cardiac Troponins (cTn) and Interleukin-1 $\beta$ (IL-1 $\beta$ ). Moreover, heart tissues catalase (CAT), glutathione peroxidase $\left(\mathrm{GP}_{\mathrm{x}}\right)$, reduced glutathione $(\mathrm{GSH})$ and L-Malondialdhyde (L-MDA) were also determined. The obtained results showed a significant increase in serum cardiac marker enzymes (CK-MB and LDH) activities, cTn and IL-1 $\beta$ concentrations in addition to L-MDA in heart tissues of ISO-induced myocardial injury in rats. However, GPx and CAT activities and GSH concentration in heart tissues of myocardial infarction induced in rats were markedly decreased. Curcumin treatment was able to protect rat myocardium against isoproternol induced myocardial ischemic damage and the protective effect was attributed to its antioxidant properties by inhibiting free radical generation.

Keywords: isoproterenol, curcumin, myocardial infarction, oxidative stress, cardiac marker enzymes.

(http://www.bvmj.bu.edu.eg) (BVMJ-35(1): 375-387, 2018)

\section{INTRODUCTION}

Cardiovascular diseases (CVDs) such as hypertension and myocardial infarction (MI) are the most important causes of mortality in developing countries due to changing lifestyles (Rajadurai and Prince, 2007 b). Myocardial infarction (MI) is one of the main causes of death from cardiovascular disease. MI is defined as an acute condition of 
necrosis of the myocardium that occurs as a result of imbalance between coronary blood supply and myocardial demand (Upaganlawar and Balaraman, 2010) and (Mudagal et al., 2011). Ischemia is caused due to reduced blood supply to heart causes several biochemical alterations which may lead to cardiac dysfunction ultimately cell death. It is well recognized that free radicals generated in ischemic tissues causes metabolic stresses which results in degradation of tissue defense system, leading to myocardial damage and necrosis (Ojha et al., 2011). Myocardial infarction increases the generation of reactive oxygen species in ischemic tissue, bringing about oxidative damage of membrane lipids, proteins, carbohydrates, DNA and brings changes in the mechanical, electrical, structural and biochemical properties of the heart (Wang et al., 2009), thus a great deal of research is focused on the role of antioxidants in the prevention of many human diseases, particularly atherosclerosis, congestive heart failure and myocardial ischemia reperfusion injury (Patel et al., 2010 and Tinkel et al., 2012).

Isoproterenol is a synthetic adrenergic agonist that causes severe stress in the myocardium resulting in infarct like necrosis of the heart muscle (Upaganlawar et al., 2011). Experimental and clinical studies on heart failure have shown that there is increased generation of reactive oxygen species such as super oxide anion $\left(\mathrm{O}^{-}\right)$and hydroxyl radical $\left(\mathrm{OH}^{-}\right)$which are involved in the formation of lipid peroxide, cell membrane damage, and destruction of antioxidative defense system (Rajadurai and Prince, 2007a). Since pathophysiological, biochemical, morphological functional alterations and histopathological lesions following isoproterenol administration in rats are similar to those in human MI, the ISP - induced MI serves as a well standardized model to study the beneficial effects and mechanism of many drugs and the efficacy of various natural and synthetic cardio-protective agents (Mladenka et al., 2009). Isoproterenol induced myocardial infarction (MI) in rats is accompanied with an increase in cardiac marker enzymes and lysosomal hydrolyses (Sathish et al., 2003).

Curcumin is an orange yellow crystalline powder; a hydrophobic polyphenol derived from the rhizome of the herb Curcuma longa has a wide spectrum of biological and pharmacological activities. Chemically, curcumin is a bis- $\alpha, \beta$-unsaturated $\beta$-diketone, which exhibits keto-enol tautomerism having a predominant keto form in acidic and neutral solutions and stable enol form in alkaline medium, practically insoluble in water and ether but soluble in ethanol, dimethylsulfoxide (DMSO) and acetone (Aggarwal et al., 2003). Curcumin was demonstrated to have antioxidative (Lee et $a l ., 2009$ ) and iron-chelating effects (Ishihara and Sakagami, 2005). It had antiinflammatory (Kim et al., 2008), antiangiogenic (Duvoix et al., 2005), antimutagenic (Aggarwal et al., 2003), anticoagulant and antidiabetic activities (Srinivasan and Menon, 2003). Additionally, Curcumin had antifungal, antiviral, antibacterial, antifibrotic, anti-venom, antiulcer, cardioprotective, hypotensive and hypocholesterolemic activities (Kurup and Barrios, 2008). Also, it had anti-HIV (Dickinson et al., 2003), adaptogenic and anti-infectious (Srinivas et al., 1992), and ant ischemic activities (Yadav et al., 2009). The present study investigated the prospective protection and anti-inflammatory effect of curcumin against myocardial infarction induced by isoprotrenol in rats.

\section{Materials and methods}

\subsection{Experimental animals:}

Forty-eight male albino rats, 5-6 weeks old age and weighting about 150-200 g were used 
in the experimental investigation of this study. Rats were obtained from the Laboratory Animal Research Center, Faculty of Veterinary Medicine, and Benha University. Animals were housed in separate metal cages; fresh and clean drinking water was supplied ad-libtium. Rats were kept at a constant environ-mental and nutritional condition throughout the period of experiment. The animals were left 14 days for adaptation before the beginning of the experiment.

\subsection{Antioxidant agents and chemicals:}

The antioxidant compounds and chemicals used in the present study were:

a. Curcumin

Curcumin (purity 99\%) is an orange yellow powder was manufactured by Fluka Co for chemicals and purchased from Elgoumhouria Co. for trading Chemicals Medicines and Medical Appliances, Egypt.

Preparation and dosage of Curcumin: Curcumin was dissolved in $7 \%$ DMSO (dimethylsulfoxide solution) (Aggrewal et al., 2003) and administered to rats orally at a dose level of $(200 \mathrm{mg} / \mathrm{kg} \mathrm{b.wt})$ once daily for 30 days.

b. Isoproterenol

Isoproterenol hydrochloride: was purchased from Sigma chemicals Co. Isoproterenol was dissolved in normal saline and injected intraperitoneally (I.P.) at the dose level of $(20 \mathrm{mg} / \mathrm{kg} \mathrm{b.wt})$ twice at an interval of 24 hours.

Preparation of isoproterenol injection: Twenty $\mathrm{mg}$ of isoproterenol powder was dissolved in $1 \mathrm{ml}$ saline solution. The solution was injected intraperitoneally at a dose of $20 \mathrm{mg} / \mathrm{kg}$ b.wt, twice for two consecutive days, at an interval of 24 hours for induction of myocardial infarction (Saravanan and Prakash, 2004).

\subsection{Experimental design:}

A total number of 48 rats were divided into six main equal groups, 8 rats each, as follow:
1) Group I: (normal control): Rats were administered $0.9 \%$ orally via intragastric intubation for 30 days.

2) Group II :( Curcumin): Rats received curcumin $(200 \mathrm{mg} / \mathrm{kg} \mathrm{b.wt} /$ day) orally for 30 days.

3) Group III: (Acute myocardial infarction): Rats injected isoproterenol hydrochloride $(20 \mathrm{mg} / \mathrm{kg}$ b.wt/i.p) twice at an interval of 24 hours on $29^{\text {th }}$ and $30^{\text {th }}$ days of experiment.

4) Group IV: (Chronic myocardial infarction): Rats injected isoproterenol hydrochloride $(20 \mathrm{mg} / \mathrm{kg} \mathrm{b.wt} / \mathrm{i} . \mathrm{p})$ twice at an interval of 24 hours on the $1^{\text {st }}$ and $2^{\text {nd }}$ days of experiment.

5) Group V:(Acute myocardial infarction + curcumin protected): Rats received curcumin (200 mg/kg b.wt/day) orally for 30 days and at the $29^{\text {th }}$ and $30^{\text {th }}$ days, then all rats were injected isoproterenol hydrochloride (20mg/kg b.wt/i.p) twice at an interval of 24 hours.

6) Group VI (Chronic myocardial infarction + curcumin treated): Rats injected isoproterenol hydrochloride $(20 \mathrm{mg} / \mathrm{kg}$ b.wt/i.p) twice at an interval of 24 hours at the $1^{\text {st }}$ and $2^{\text {nd }}$ days of experiment, then all rats were administered curcumin(200 mg/kg b.wt/day) orally for 30days.

\subsection{Sampling:}

Blood samples and cardiac tissue specimens were collected at the end of experiment after 30 days from all animal groups, At the end of experimental period, rats were anesthetized by (pentobarbital sodium $35 \mathrm{mg} / \mathrm{kg}$ i.p) and the rats were sacrificed by cervical decapitation.

\subsubsection{Blood samples:}

Blood samples were collected from reteroorbital venous plexus of eyes in clean, dry screw capped tubes, the samples were allowed to coagulate at room temperature for $30 \mathrm{~min}$, then centrifugated at 3000 r.p.m for $15 \mathrm{~min}$. The clean clear serum was aspirated by pasture pipette and received in dry sterile sample tube, stored at $-20^{\circ} \mathrm{c}$ until used for subsequent biochemical analysis. All sera 
were analyzed for the following parameters: Creatine kinase MB (CK-MB), Lactate dehydrogenase (LDH), Troponins (cTn) and Interleukin-B (IL-1B).

\subsubsection{Tissue samples:}

At the end of each experimental period, rats were sacrificed by cervical decapitation. The heart specimens were quickly removed, then perfused with cold saline to exclude the blood and blotted on filter paper and stored at-20 C until analysis. All heart tissues were used for determination of: Catalase (CAT), Glutathione peroxidase $\left(\mathrm{GP}_{\mathrm{x}}\right)$, Reduced glutathione (GSH) and, L-Malondialdhyde (L-MDA).

Briefly, heart tissues were cut, weighed and minced into small pieces, homogenized with a glass homogenizer in 9 volumes of ice-cold $0.05 \mathrm{mM}$ potassium phosphate buffer $(\mathrm{pH}$ 7.4) to make $10 \%$ homogenates. The homogenates were centrifuged at 6000 r.p.m for 15 minutes at $4{ }^{\circ} \mathrm{C}$ then the resultant supernatant was used for the determination of the following parameters: CAT, GPx and LMDA. Also, $0.2 \mathrm{~g}$ of hear tissues were minced into small pieces homogenized with a glass homogenizer in $0.4 \mathrm{ml}$ of $25 \%$ metaphosphoric acid (MPA) (ref. No.: 253433-4, Sigma-Aldrich, Germany), then 1.4 $\mathrm{mL}$ of distilled water was added, mixed and incubated for 1 hour and centrifuged for 10 min at 3,000 r.p.m then the clean supernatant was removed and used for determination of GSH concentration.

\subsection{Biochemical analysis:}

Serum creatine kinase-MB and lactate dehydrogenase (LDH) activities were determined according to the method described by (Urdal and Lanndaa, 1979) and (Scientific Committee, 1982), respectively. Serum troponin concentration was determined by the method of (marieb, 2004) and (black, 2005) and serum Interleukin-1 $\beta$ level was determined using Rat IL-1 beta ELISA (Ray Biotech, IncCompany,Cat\#:ELR-
IL1b)according to the manufacturer's instruction. Moreover, heart tissue Catalase (CAT), Glutathione peroxidase $\left(\mathrm{GP}_{\mathrm{x}}\right)$, Reduced glutathione (GSH), and LMalondialdhyde (L-MDA) were determined according to the methods described by Sinha, (1972), Gross et al., (1967), Moron et al., (1979) and Ohkawa et al., (1979), respectively.

2.6. Statistical analysis:

The results were expressed as mean $\pm \mathrm{SE}$ using SPSS software program version 16 (SPSS $\odot$ Inc., USA). The data were analyzed using one-way ANOVA to determine the statistical significance of differences among groups. Duncan's test was used for making a multiple comparison among the groups for testing the inter-grouping homogeneity. Values were considered statistically significant when $\mathrm{p}<0.05$.

\section{RESULTS}

The data shown in table (1) illustrated that, serum Creatine kinase MB (CK-MB), Lactate dehydrogenase (LDH), Troponins (cTn) and Interleukin-B (IL1B) conc. were significantly elevated $(\mathrm{P} \leq 0.05)$ in rats received ISO alone when compared with the control group. Curcumin treatment to isoprotrenol injected rats significantly decreased the same parameters, prevented these changes, and resulting in a remarkable protection when compared with isoproterenol groups (acute and chronic groups).

The data summarized in table (2) revealed that, isoproterenol induced myocardial infarction in rats caused significant reduction in heart tissue CAT and GPx activities and GSH level with marked elevation in L-MDA concentration when compared to normal control group. However, in the groups that received ISO and curcumin, these cardiac antioxidant parameters (CAT, GPx, GSH) were significantly elevated and administration 
of curcumin induce noticeable changes in ISO myocardial infarction rats causing a significant decrease in elevated heart tissue LMDA in comparison with the ISO group.

Table1. Effect of curcumin administration on serum CK-MB and LDH activities, cTn and IL-1 $\beta$ concentrations in ISO-induced myocardial injury in rats.

\begin{tabular}{|c|c|c|c|c|}
\hline Exp. groups & CK-MB (U/L) & LDH (U/L) & cTn (pg/ml) & $\mathrm{IL}-1 \beta(\mathrm{pg} / \mathrm{ml})$ \\
\hline Normal control & $57.22^{c} \pm 4.61$ & $367.44^{\mathrm{c}} \pm 21.90$ & $11.95 \pm 0.79^{d}$ & $214.04^{\mathbf{c}} \pm 19.81$ \\
\hline Curcumin & $99.60^{b} \pm 7.40$ & $494.78^{\mathbf{b}} \pm 6.27$ & $51.23 \pm 1.65^{\mathbf{b}}$ & $428.60^{b} \pm 58.70$ \\
\hline ISO (Acute) & $188.6^{\mathrm{a}} \pm 16.889$ & $646.70^{b} \pm 27.319$ & $68.58^{\mathrm{a}} \pm 2.83$ & $622.20^{\mathrm{a}} \pm 10.30$ \\
\hline protected (CUR +ISO) & $90.80^{\mathbf{b}} \pm 22.04$ & $406.85^{b c} \pm 40.8$ & $25.91^{c} \pm 2.76$ & $383.91^{\mathbf{b}}+45.93$ \\
\hline ISO (chronic) & $214.64^{\mathrm{a}} \pm 13.269$ & $810.93^{\mathrm{a}} \pm 35.94$ & $103.86^{\mathrm{a}} \pm 3.78$ & $768.70^{a} \pm 36.80$ \\
\hline Treated (ISO+CUR) & $95.97^{c_{ \pm}} 7.71$ & $327.53^{c} \pm 29.37$ & $19.77^{\mathrm{c}} \pm 2.47$ & $168.36^{\mathbf{b}} \pm 15.90$ \\
\hline
\end{tabular}

Data are presented as $($ Mean \pm S.E). $\quad$ S.E $=$ Standard error.

Mean values with different superscript letters in the same column are significantly different at $(\mathrm{P} \leq 0.05)$.

Table 2. Effect of curcumin administration on heart tissue CAT and GPx activities, GSH and L-MDA concentrations in ISO-induced myocardial injury in rats.

\begin{tabular}{|c|c|c|c|c|}
\hline Parameters & $\begin{array}{c}\text { CAT } \\
(\mathrm{mmol} / \mathrm{g} . \text { tissue })\end{array}$ & $\begin{array}{c}\text { GPx } \\
\text { (ng/g. tissue) }\end{array}$ & $\begin{array}{c}\text { GSH } \\
\text { (ng/g. tissue) }\end{array}$ & $\begin{array}{c}\text { L-MDA } \\
(\mathrm{mmol} / \mathrm{g} . \text { tissue })\end{array}$ \\
\hline Exp. groups & & & & \\
\hline Normal & $79.23^{a} \pm 6.60$ & $0.80^{\mathrm{a}} \pm 0.11$ & $7.30^{\mathrm{a}} \pm 1.42$ & $55.21^{b} \pm 6.85$ \\
\hline Curcumin & $40.54^{\mathbf{b}} \pm 3.30$ & $0.30^{\mathbf{b c}} \pm 0.03$ & $3.1^{\mathbf{b}} \pm 0.90$ & $50.83^{\mathbf{b}} \pm 4.70$ \\
\hline ISO (Acute) & $29.22^{\mathbf{b}} \pm 3.91$ & $0.21^{c_{ \pm}}+0.04$ & $2.81^{\mathbf{b}} \pm 0.65$ & $131.81^{\mathrm{a}} \pm 16.96$ \\
\hline protected (CUR +ISO) & $72.63^{a} \pm 5.43$ & $0.51^{c_{ \pm}} \pm 0.04$ & $7.31^{\mathrm{a}} \pm 0.70$ & $54.55^{b} \pm 6.71$ \\
\hline ISO (chronic) & $36.24^{\mathbf{b}} \pm 3.80$ & $0.23^{\mathbf{b}} \pm 0.05$ & $3.21^{\mathrm{b}} \pm 1.21$ & $135.05^{\mathrm{a}} \pm 16.05$ \\
\hline Treated (ISO+CUR) & $73.50^{a}+8.50$ & $0.66^{\mathrm{a}} \pm 0.03$ & $8.31^{\mathrm{a}} \pm 0.60$ & $52.24^{\mathbf{b}}+11.20$ \\
\hline
\end{tabular}

Data are presented as $($ Mean \pm S.E). $\quad$ S.E $=$ Standard error.

Mean values with different superscript letters in the same column are significantly different at $(\mathrm{P} \leq 0.05)$.

\section{DISCUSSION}

Acute myocardial infarction (AMI) is commonly known as heart attack. It results from the interruption of blood supply to a part of the heart causing heart cells to die. The resulting ischemia (restriction in blood supply) and ensuing oxygen shortage, can cause damage or death (infarction) of myocardium if left untreated (Thygesen et al.,
2012).The present study evaluated the effects of curcumin treatment on myocardial infarction resulting from ISO injection. Injection of isoprotrenol $(20 \mathrm{mg} / \mathrm{kg}$ b. wt., twice for two consecutive days at an interval of 24 hours) significantly elevated the serum activity of creatine kinase-MB (CK-MB) and lactate dehydrogenase ( $\mathrm{LDH})$ in addition to troponins (cTn) and interleukin-1 $\beta$ (IL-1 $\beta$ ) 
concentrations. This result agreed with (Sharmila and Rajadurai, 2012) who recorded significant increase in CK-MB and $\mathrm{LDH}$ activities in ISO injected rats. The cardiac marker enzymes may be due to the damage caused by ISO, the cardio toxic agent to the myocardial cells (Lalitha et al., 2012). The activity of CK-MB is the most diagnostic for MI because of the marked abundance of this isoenzyme in myocardium and virtual absence from most other tissues and its consequent sensitivity (detection of necrosis of less than $100 \mathrm{mg}$ of myocardium). The magnitude and persistence of elevation are useful in estimating the extent of infarction (Sobel, 1992). Heart damage induced by ISO was indicated by elevated levels of the marker enzyme such as CK-MB in serum as reported by (Ahmed et al., 2004). Furthermore, cardiac enzymes were significantly increased in isoproterenol treated rats as reported by earlier studies (Farvin et al., 2004), may be due to generation of free radicals released from damaged myocardial tissue (Balarraman et al., 2007). Extent of cardio-protection offered by the drug is associated with significant attenuation of plasma creatine kinase (Gao et al., 2000) and LDH activities (Hung et al., 2000).

Administration of curcumin before and after isoproterenol injection (protective and treated group) reduced elevated serum CK-MB and $\mathrm{LDH}$ activities at the end of experimental period when compared to ISO group. This decrease may be due to the fact that, curcumin has established antioxidants and antiinflammatory activities that offer promise in the treatment of cardiovascular diseases. For example, it can reduce creatine kinase $(\mathrm{CK})$ and lactate dehydrogenase (LDH) activities Cheng et al. (2005), Dikshit et al. (1995), Nirmala and Puvanakrishnan (1996 b) and Yao et al. (2004). Likewise, Yousef et al., (2008). Moreover, increase in the concentration of serum cardiac Troponin in
ISO injected rats may be due to the necrosis induced by ISO is mainly located in the subendocardial region of the left ventricle and the interventricular septum (Chappel et al. 1959). The mechanism of cardiac impairment caused by ISO is not clear and appears to be complex. Oxidative stress is probably one of the main causes (Tappia et al. 2001; Ojha et al. 2010). The positive inotropic and chronotropic effects of ISO at high doses lead to a depletion in the myocardial energy reserves, and thus result in biochemical and structural changes that may be responsible for the development of cardiac injury (MahammadRahmathulla and Kodidhela, 2013). Troponins represent a specific and sensitive tool for the assessment of cardiac damage.

Acute myocardial infarction (AMI) and heart failure (HF) are characterized by an intense inflammatory response that contributes to progression of the injury and dysfunction (Seropian et al .2014). Tissue injury stimulates the formation of the inflammation and the production of interleukin IL-1 $\beta$ (Toldo et al. 2015) and (VanTassell et al., 2013). Isoproterenol is a synthetic catecholamine that has positive inotropic and chronotropic effect. At therapeutic doses it increases cardiac output, however when administered in large doses it was reported to cause severe oxidative stress in the myocardium leading to necrosis of the left ventricular heart muscle (Alcantara et al.,2011). Increased concentrations of intracellular cAMP have been reported to inhibit the production of pro-inflammatory cytokines and the induction of enzymes that regulate inflammatory molecules (Zhang et al.,2004). IL-1 $\beta$ is the earliest cytokineproducing inflammatory reaction. Isoproterenol stimulated inflammatory factors (TNF- $\alpha$, IL-1 $\beta$ ) thereby extending significant cardio-protective effect against ISO induced 
myocardial injury in rats (DeviSampath and Vijayaraghavan, 2007).

Curcumin is a highly pleiotropic molecule that interacts physically with its numerous targets. As a result, curcumin exerts its antiinflammatory effects via several mechanisms, i.e., curcumin down regulates the nuclear factor- $\kappa \mathrm{B}(\mathrm{NF}-\kappa \mathrm{B})$, resulting in a decrease in the expression of tumor necrotic factor- $\alpha$ (TNF- $\alpha$ ), interleukin-1B (IL-1B) and interleukin-6 (IL-6) (Toldo et al. 2015). In the earlier study curcumin administration decreased TNF- $\alpha$, IL-1 $\beta$ and IL-6 levels. TNF- $\alpha$, and IL-6 are multifunctional cytokines produced primarily by activated monocytes and macrophages; they play a crucial role in the initiation and continuation of mucosal inflammation and immunity (Tracey and Cerami, 1994). These cytokines are involved in many cell processes including apoptotic cell death, metabolism, inflammation, thrombosis and fibrinolysis (Nilsen et al., 1998).

In the current study, injection of isoproterenol (20 mg/kg b. wt., twice for two consecutive days at an interval of 24 hours) significantly lowered the heart tissue CAT, GPx, GSH and significantly elevated L-MDA concentration. Higher levels of production of $\mathrm{H}_{2} \mathrm{O}_{2}$ lowered the activity of CAT (Stief, 2003). The activity of CAT was found to be significantly lower in ISO treated rats as compared with the control group, and after treatment with curcumin, CAT activity was found significant increase in heart tissue. ISO-caused oxidative stress in the heart as evidenced by lowered activities of myocardial catalase, which is consistent with an earlier study (StanelyMainzen, 2011). ISOmetabolism produce quinones, which react with oxygen to produce superoxide anions and hydrogen peroxides leading to oxidative stress and lowered endogenous antioxidant system (Rathore et al., 2000). Oxidative stress coexists with a reduction in antioxidant status (Sampath and Kannan, 2009). Treatment with curcumin in ISO induced myocardial infarction in rats exhibited significant increase in the heart tissue CAT and GPx activities. These results were nearly similar to those recorded by (Popov et al., 2003) who reported that; curcumin normalized the antioxidant enzymes activities (CAT) of heart tissue. Curcumin has ability to scavenge free radicals, interacting with oxidative cascade, quenching oxygen, inhibiting oxidative enzymes and chelating metal ions and inhibits lipid peroxidation (Kamalakkannan et al., 2005).

Reduced glutathione GSH is an nonenzymatic antioxidants (free radical scavenger), preventing damage to important cellular components caused by reactive oxygen species such as free radicals and peroxides and is important substance in the cellular detoxication process, so the oxidation of GSH can also occur due to toxic metabolites, chemicals, and drugs (Pompella et al., 2003). Glutathione is involved in the destruction of hydrogen peroxide GSH dependent. Enzymes provide a second line of defense as they primarily detoxify the noxious byproducts generated by ROS and also help to prevent propagation of free radicals (Gumieniczek, 2005). GPx detoxify peroxides by reacting them with GSH. GST are detoxifying enzymes that catalyze the conversion of toxic products to fewer toxic products by conjugation with GSH. Low GPx activity in ISO- induced myocardial infarcted rats heart might be due to the low GSH content in the heart.

Since GSH is the substrate for GPx (Dominguez et al., 1998). The decreased availability of GSH is the reason for the lowered activity of GST observed in ISO induced myocardial infarcted rats. The decreased GSH level in MI might be due to its increased utilization in protecting thiol groups containing proteins from the action of free radicals. Pretreatment with diosmin improved 
the activity of GSH dependent enzymes and the concentration of GSH in the heart of ISOinduced myocardial infracted rats, by its antioxidant effect (SheelaSasikumar and ShyamalaDevi, 2000). Curcumin administration in ISO injected rats resulted in a significant increase in the heart tissue GSH concentration. The significant restoring of depleted GSH level in target organs with CUR treatment could be either due to its enhanced synthesis or improved glutathione reductase activity (Naik et al., 2011), these CUR's antioxidant properties may be due to its ability to induce GSH-linked defense mechanisms against oxidative stress (Piper et $a l ., 1998)$ by protecting SH group of GSH and activating GST- $\alpha$ (Kunchandy and Rao, 1990).

A significant increase in heart tissue L-MDA was observed in ISO group when compared to the control group. this may be due to excessive formation of free radicals by autooxidation of ISO and activation of the lipid peroxidative process, resulting in an irreversible damage to the heart in animals subjected to ISO stress (Shaik et al., 2012). The increased also might be due to free radical mediated membrane damage (Nagar, 2011). Malondialdhyde (MDA), a stable metabolite of the reactive oxygen species (ROS)-mediated lipid peroxidation cascade, was measured as previously reported (Sun et al., 2005). During MI, the subsequent generation of lipid peroxides and lipid hydroperoxides results in the initiation of chain reactions that could damage the myocardium. The observed increase in these lipid peroxidation products indicates enhanced lipid peroxidation leading to myocardial injury and failure of the antioxidant defense mechanism to prevent the formation of excess free radicals. Treatment with curcumin in myocardial injury induced in rats resulted in a significant decrease in heart tissue L-MDA concentration at the end of the experiment when compared with ISO induced myocardial injury groups These results are in agreement with (Bonte, 1997) who reported that, treatment with curcumin and tetra hydro curcumin were protect the cells through attenuation of lipid peroxidation and decreased the production of free radical derivatives, as evident from the decreased levels of TBARS and hydro peroxides. Thus, curcumin and tetrahydrocurcumin offered protection against oxidative stress by scavenging of free radicals.

\section{Conclusion}

From the obtained results it could be concluded that, curcumin administration significantly curtails the effects of ISO induced myocardial infarction. This attenuation is verified by remarkable protection effect, decline cardiac enzymes (CK-MB and LDH) activity and cTn concentration, Powerful antioxidant, enhance the activity of CAT, GPx, increase GSH level and reduce(L-MDA) concentration with potent anti- inflammatory influence as it diminishes (IL-1B) production. These abilities of curcumin make it a potential drug for inhibiting myocardial infarction.

\section{REFERENCES}

Aggarwal, B.B.; Kumar, A. and Bharti, A.C. (2003): Anticancer potential of curcumin: Preclinical and clinical studies. Anticancer Res, 23: 398.

Ahmed, K.K.; Rana, A.C. and Dixit, V.K. (2004): Effect of calotropispocera Latex on isoproterenol induced myocardial infarction in albino rats. Phytomedicine, 11(4):327 -330.

Alcantara, E.H.; Shin M.Y.; Sohn HY, Park YM, Kim T, Lim JH, Jeong HJ, Kwon ST and Kwun, I.S. (2011): Diosgenin stimulates osteogenic activity by increasing bone matrix protein synthesis and bone-specific 
transcription factor Runx2 in osteoblastic MC3T3-E1 cells. J NutrBiochem, 22(11):1055-1063.

Balarraman, G.; Rangasamy, R.; Rangasamy, A. and Nanjappan, D. (2007): Biochemical studies on protective effect of betaine on mitochondrial function in experimentally induced myocardial infarction in rats. Health Sci, 53: 671-681.

Black, j. (2005): A Sensitive Cardiac Troponin T Assay in stable coronary Artery Disease.Journal of Clinical Pathology, 2 (2): 57-60.

Bonte, F. (1997): Protective effect of curcuminoids on epidermal skin cells under free oxygen radical stress .Plant Med, 63:265-266.

Chappel, C.L.; Rona, G.; Balazs, T. and Gaudry, R. (1959): Severe myocardial necrosis produced by isoproterenol in the rat. Arch IntPharmacodynTher, 122: 123-128.

Cheng, A.L.; Hsu, C.H.; Lin, J.K.; Hsu, M.M.; Ho, Y.F.; Shen, T.S.; Ko, J.Y.; Lin, J.T.; Lin, B.R., Ming-Shiang, W.; Yu, H.S.; Jee, S.H.; Chen, G.S.; Chen, T.M.; Chen, C.A.; Lai, M.K.; Pu, Y.S.; Pan, M.H.; Wang, Y.J.; Tsai, C.C. and Hsieh, C. Y. (2005): Phase I clinical trial of curcumin, a chemopreventive agent, in patients with high risk or premalignant lesions. Anticancer Res, 21(4B): 2895-2900.

Devi-Sampath, P. and Vijayaraghavan, $\mathrm{K}$. (2007): Cardioprotective effect of amangostin, a xanthone derivative from mangosteen on tissue defense system against isoproterenol-induced myocardial infarction in rats. $\mathrm{J}$ BiochemMolToxicol, 21: 336-339.
Dickinson, D.A.; Iles, K.E.; Zhang, H.; Blank, V. and Forman, H.J. (2003): Curcumin alters EpRE and AP-1 binding complexes and elevates glutamatecysteine ligase gene expression. FASEB, J17:473-475.

Dikshit, M.; Rastogi, L.; Shukla, R.; Srimal, R.C. (1995): Prevention of ischaemiainduced biochemical changes by curcumin\& quinidine in the cat heart. Indian J Med Res, 101:31-35.

Dominguez, C.; Ruiz, E.; Gussinye, M. and Carrascoca, A. (1998): Oxidative stress at onset and in early stages of type-1 diabetes in children and adolescents. Diabetes Care 21: 1736-1742.

DuVoix, A.; Blasius, R.; Delhalle, S.; Schnekenburger, M.; Morceau, F.; Henry, E.; Dicato, M.; Henry, E. and Diederich, M. (2005): Chemo preventive and therapeutic effect of curcumin. Cancer Lett, 223:181-190.

Farvin, K.H.; Anandan, R.; Senthil, K.S.H.; Shiny, K.S.; Sankar, T.V. and Thankappan, T.K. (2004): Effect of squalene on tissue defense system in isoproterenol induced myocardial infarction in rats. Pharmacol Res, 50: 231-236.

Gao, F.; Chen, J.; Lopez, B.L.; Christopher, T.A.; Juan, L.G.; Paul, L.; Robert, R.; Xin, L.M.; Hlstein, E.H. and Tian-Li, Y. (2000): Comparison of bisoprolol and carvedilol, cardioprotection in a rabbit ischemia and reperfusion model. Eur J Pharmacol, 406: 109-116.

Gross， R.T.; Bracci， R.; Rudolph， N.; Schroeder, E. and Kochen, J.A. (1967): Hydrogen peroxide toxicity and detoxificatn in erythrocytes of newborn infants. Blood, 29:481-493. 
Gumieniczek, A. (2005): Effects of repaglinide on oxidative stress in tissues of diabetic rabbits. Diabetes Res ClinPract, 68: 89-95.

Hung, L. M.; Chen, J. K.; Lee, R. S.; Luang, H. C. and Jai Su, M. (2000): Beneficial effects of astringinin arevertrol analogue, on the ischemia and reperfusion damage in rat heart. Free RadicBiol Med, 30: 877-883.

Ishihara, M. and Sakagami, H. (2005): Reevaluation of cytotoxicity and iron chelation activity of three $\beta$-diketones by semiempirical molecule orbital method. In vivo,19:119-123.

Kamalakkannan, N.; Rukkumani, R.;Varma, P.S.;Viswanathan, P.; Rajasekharan, K.N. and Menon, V.P. (2005): comparative effects of curcumin and an analogue of curcumin in carbon tetrachloride-induced hepatotoxicity in rats. Basic \& Clinical Pharmacology \& Toxicology, 97: 15-21.

Kim, K.; Pae, H.O.; Zhung, M.; Ha, H.Y.; Ha, Y.A.; Chai, K.Y.; Cheong, Y.K.; Kim, J.M. and Chung, H.T. (2008): Involvement of anti-inflammatory heme oxygenase- 1 in the inhibitory effect of curcumin on the express of proinflammatory INO synthase in RAW264.7 macrophages. Biomed Pharmaco, 62: 630-636.

Kunchandy, E. and Rao, M.N.A. (1990): Oxygen radical scavenging activity of Curcumin. Int J Pharmaco, 58: 237240.

Kurup, V.P. and Barrios, C.S. (2008): Immunomodulatory effects of curcumin in allergy (review). MolNutr Food Res, 52:1031-1039.
Lalitha, G.; Poornima, P.; Archanach, A. and Padma, V. (2012): Protective effect of neferine against isoproterenol induced cardiac toxicity. CardiovascToxicol, 13(2): 168-179.

Lee, K.; Ab Aziz, F.H.; Syahida, A.; Abas, F.; Shaari, K.; Israf, D.A. and Lajis, N.H. (2009): Synthesis and biological evaluation of curcumin-like diarylpentanoid analogues for antiinflammatory, antioxidant and antityrosinase activities. Eur J Med Chem, 44(8):3195-3200.

MahammadRahmathulla, S.B. and Kodidhela, L. D. (2013): Origination and development of isoproterenol-induced myocardial infarction in male Wistar rats. Int Res J Pharm, 4: 27-35.

Marieb, E.N. (2004): Human anatomy \& physiology. $9^{\text {th }}$ ed, $42(2): 450-470$.

Mladenka, P.; Hrdina, R.; Bobrovova, Z.; Semecky, V.; Vavrova, J.; Holeckova, M.; Palicka, V.; Mazurava, Y. and Nachtiqal, P. (2009): Cardiac biomarkers in amodel of acute catecholamine Cardiotoxicity. Hum ExpToxicol, 28: 631-640.

Moron, M.S.; Depierre, J.W. and Mannervik, B. (1979): Levels of glutathione, glutathione reductase and glutathione S-transferase activities in rat lung and liver. BiochimicaetBiophysica ACTA, 582:67-78.

Mudagal, M.; Karia, S. and Goli, D. (2011): Preventive effect of Rhododendron arboretum on cardiac markers, Lipid peroxides and antioxidants in normal and isoproterenol induced myocardial necrosis in rats. African J Pharmacology, 5(6): 755-763. 
Nagar, V. (2011). Cardioprotective effects of commiphoramukul against isoprenaline-induced cardiotoxicity. J. Environmental Biology, 32: 731-738.

Naik, S.R.; Thakare, V.N. and Patil, S.R. (2011): Protective effect of curcumin on experimentally inducedinflammation, hepatotoxicity and cardiotoxicity in rats: Evidence of its antioxidant property. Exp and ToxicoPatho, 63:419-431.

Nilsen, E.M.; Johansen, F.E.; Jahnsen, F.L.; Lundin, K.E.; Scholz, T.; Brandtzaeg, P. and Haraldsen, G. (1998): Cytokine profiles of cultured micro-vascular endothelial cells from the human intestine. Gut, 42: 635-642.

Nirmala, C. and Puvanakrishnan, R. (1996): Effect of curcumin on certain lysosomal hydrolases in isoproterenolinduced myocardial infarction in rats. BiochemPharmacol, 51:47-51.

Ohkawa, H.; Onishi, N. and Yagik. (1979): Assay for lipid peroxides in animal tissue by thiobabituric acid reaction. Anal.Biochem, 95: 351-358.

Ojha, S.; Bhatia, J.; Arora, S.; Golechha, M.; Kumari. S. and Arya, D. S. (2011): Cardioprotective effects of commiphoramukul against isoprenaline-induced cardiotoxicity. J Environmental Biology, 32: 731-738.

Ojha, S.; Nandave, M.; Arora, S. and Arya, D.S. (2010): Effect of Isoproterenol on Tissue Defense Enzymes, Hemodynamic and Left Ventricular Contractile Function in Rats. Ind J Clin Biochem, 25: 357-361.

Patel,V.; Upaganlawar, A.; Zalawadia, R.; and Balaraman, $\mathrm{R}$. (2010): Cardioprotective effect of melatonin against isoproterenol induced myocardial infarction in rats: abiochemical, electro cardiographic and histoarchitectural evaluation. European J. Pharmacology, 644: 160168.

Piper, J.T.; Singhal, S.S.; Salameh, M.S.; Torman, R.T.; Awasthi, Y.C. and Awasthi, S. (1998): Mechanisms of anticarcinogenic properties of curcumin: effect on glutathione linked detoxification enzymes in rat liver. Int $\mathrm{J}$ Bioch Cell Bio, 130: 445-56.

Pompella, A.;Visvikis, A. Paolicchi, A. De Tata, V. Alessandro F. Casini, A.F. (2003): The changing faces of glutathione, a cellular protagonist. Biochemical Pharmacology, 66 :14991503.

Popov, V.; $\quad$ Gadjeva, P;. Valkanov, S.; Popova, A. and Tolekova, A. (2003): Lipid Peroxidation, Superoxide Dismutase and Catalase Activities in Brain Tumor Tissues. Archives of Physiology and Biochemistry, 111 (5): 455- 459.

Rajadurai, M. and Prince, S. (2007a): Preventive effect of naringin on isoproterenol induced Cardiotoxicity in Wistar rats. Toxicology, 232: 216-225.

Rajadurai, M. and Prince, S.M.P. (2007b): Preventive effect of naringin on cardiac markers, electrocardiographic patterns and lysosmal hydrolases in normal and isoproternol induced myocardial infarction in wistar rats. Toxicology, 230: 178-188.

Rathore, N.; Kale, M.; John, S. and Bhatnagar, D. (2000): Lipid peroxidation and antioxidant enzymes in isoproterenol induced oxidative 
stress in rat erythrocyte. Indian $\mathrm{J}$ PhysiolPharmacol, 44: 161-166.

Sampath, P. and Kannan, V. (2009): Mitigation of mitochondrial dysfunction regulation of eNOS expression during experimental myocardial necrosis by alphamangostin, axanthonic derivative from carciniamangostana. Information Health Care, 32(4): 344-352.

Saravanan, G. and Prakash, J. (2004): Effect of garlic (Allium sativum) on lipid peroxidation in experimental myocardial infarction in rats. $\mathrm{J}$ Ethnopharm, 94: 155-158.

Sathish, V.; Ebenzar, K.K. and Devaki, T. (2003): Synergestic effect of nicorandil and amlodipine on lysosmal hydrolases during experimental myocardial infarction in rats. Biomed Pharmacol, 57(7): 309-13.

Scientific

Committee

(1982):

Recommendations pour la mesure de la concentration catalyique de lactate deshidrogenasedans le serum human a $30^{\circ} \mathrm{C}$. Ann. Biol. Clin, 40: 87-164.

Seropian, I.M.; Toldo, S.; VanTassell, B.W and Abbate, A. (2014): Antiinflammatory strategies for ventricular remodeling following ST-segment elevation acute myocardial infarction. $\mathrm{J}$ Am CollCardiol, 63:1593-1603.

Shaik, A.; Rasool, S.; Abdulkareem, M.; Krushna, G.; Akhtar, P. and Devi, K. (2012): Maslinic acid Protects against isoproterenol induced cardiotoxicity in Albino wistar rats. J. Elsevier, 106(2): 335-337.

Sharmila, S. and Rajadurai, M. (2012): Preventive effect of bio-aq on cardiac markers, Lipids, and membrane bound enzymes in isoproternol induced myocardial infarction in rats. Asian $\mathrm{J}$ Pharm and Clinical Res, 5(2): 107-113.

SheelaSasikumar, C. and ShyamalaDevi, C.S. (2000): Protective effect of Abana-a polyherbal formulation on isoproterenol induced myocardial infarction in rats. Indian J Pharmacol, 32: 198-201.

Sinha, A.K. (1972): Colorimetric Assay of catalase. Analytical Biochemistry, 47: 389-394.

Sobel, B.E. (1992): Acute myocardial infarction. In: Wyngarden, J.B.; Smith, L.H.J. and Bennett, J.C.eds: Cecil textbook of medicine, $19^{\text {th }}$ edn. W. B. Saunders Co; Philadelphia; P: 304-318.

Srinivas, L.; Shalini, V.K. and Shylaja, M. (1992): Turmerin: water soluble antioxidant peptide from turmeric. Archive of BiochemBiophys, 292(2):617-623.

Srinivasan, A. and Menon, V.P. (2003): Protection of pancreatic h-cell by the potential antioxidant bis-o-hydroxycinnamoyl methane, analogue of natural curcuminoid in experimental diabetes. J Pharm PharmSci, 6: $327-$ 333.

StanelyMainzen, P. (2011): Biochemical electrocardiographic, electrophoretic, histopathological and in vitro study on the protective effects of epicate-chin in isoproterenol induced myocardial infracted rats. Eur J Pharmacol, 671:95-101.

Stief, T. W. (2003): The physiology and pharmacology of singlet oxygen. Medical Hypotheses, 60: 567-572. 
Sun, H.Y.; Wang, N.P.; Kerendi, F.; Halkos, M.; Kin, H. and Guyton, R. A. (2005): Hypoxic postconditioning reduces cardiomyocyte loss by inhibiting ROS generation and intracellular $\mathrm{Ca}$ overload. Am J Physiol Heart CircPhysiol, 288: 1900-1901.

Tappia, P.S.; Heta, T., and Dhalla, N. S. (2001): Role of oxidative stress in catecholamine-induced changes in cardiac sarcolemmal $\mathrm{Ca} 2+$ transport. Arch BiochemBiophy, 377: 85-92.

Thygesen, K.; Alpert, J.S.; and White, H. D. (2012): Universal definition of myocardial infarction. J. Am. Coll. Cardiol, 60:2173-2195.

Tinkel, J.; Hassanain, H. and Khouri, S.J. (2012): Cardiovascular antioxidant therapy: a review of supplements, phamacotherapies, and mechanisms. Cardiol Rev, 20: 77-83.

Toldo, S.; Mezzaroma, E.; Mauro, A.G.; Salloum, F., VanTassell, B.W. and Abbate, A. (2015): The inflammasome in myocardial injury and cardiac remodeling. Antioxid Redox Signal, 22:1146-61.

Tracey, K.J. and Cerami, A. (1994): Tumor necrosis factor: a pleiotropic cytokine and therapeutic target. Annu Rev Med, 45: 491-503.

Upaganlawar, A. and Balaraman, O. (2011): Cardioprotective effects of Lagenariasiceraria Fruit Juice on isoproterenol induced myocardial infarction in wistar rats. $\mathrm{J}$ Young Pharmacists, 3(4): 297-303.

Urdal, P. and Landaa, S. (1979): Macro creatine kinase $\mathrm{BB}$ in serum, and some data on its prevalence. Clin. Chem, 25: 461-465.
VanTassell, B.W.; Toldo, S.; Mezzaroma, E. and Abbate, A. (2013): Targeting interleukin-1 in heart disease. Circulation, 128:1910-1923.

Wang, S.B.; Tian, S.; Yang, F.; Yang, H.; Yang, X. and Du, G. (2009): Cardioprotective effect of salvianolic acid A on isoproternol -induced myocardial infarction in rats. EurJpharmacol, 615(1-3): 125- 132.

Yadav, R.S.; Sankhwar, M.L.; Shukla, R.K.; Chandra, R.; Islam, F. and Khanna, V.K. (2009): Attenuation of arsenic neurotoxicity by curcumin in rats. Toxico and Applied Pharmaco, 240: 367-376.

Yao, Q. H.; Wang, D. Q.; Cui, C.C.; Yuan, Z.Y.; Chen, S.B.; Yao, X.W.; Wang, J.K. and Lian, J.F. (2004): Curcumin ameliorates left ventricular function in rabbits with pressure overload: inhibition of the remodeling of the left ventricular collagen network associated with suppression of myocardial tumor necrosis factor-alpha and matrix metalloproteinase-2 expression. Biol Pharm Bull,127:198-202.

Yousef, M. I.; El-Demerdash, F.M. and Radwan, F.M. (2008): Sodium arsenite induced biochemical perturbations in rats. Ameliorating effect of curcumin. Food Chem. Toxicol., 46 (11) :3506-11.

Zhang, B.; Perpetua, M.; Fulmer, M.; Harbrecht, B.G. (2004): JNK signaling involved in the effects of cyclic AMP on IL-1b plus IFNc-induced inducible nitric oxide synthase expression in hepatocytes. Cell Signal, 6:837-846. 